\title{
Molecular Weight Determination of a Protease Extracted from Mucor pusillus: Comparison Methods
}

\author{
Nouani Abdelouahab',2, Belhamiche Nabila3 ${ }^{3}$, Slamani Roza4, Belbraouet Slimane ${ }^{5,6^{*}}$, \\ Dako Etienne ${ }^{5,6}$, Audet Pascal ${ }^{5,6}$, Bellal Mohand Mouloud ${ }^{2}$ \\ ${ }^{1}$ Food Laboratory Technology, Boumerdes University, Boumerdes, Algeria \\ ${ }^{2}$ Laboratory of Food Technology, Superior National School of Agronomy, Algiers, Algeria \\ ${ }^{3}$ University of Bejaia, Bejaia, Algeria \\ ${ }^{4}$ National Agricultural Research Institute, Algiers, Algeria \\ ${ }^{5}$ ÉSANÉF, University of Moncton, Moncton, Canada \\ ${ }^{6}$ Centre de Recherche sur les Aliments, University of Moncton, Moncton, Canada \\ Email: ${ }^{\text {slimane.belbraouet@umoncton.ca }}$
}

Received 21 February 2015; accepted 9 March 2015; published 13 March 2015

Copyright (C) 2015 by authors and Scientific Research Publishing Inc.

This work is licensed under the Creative Commons Attribution International License (CC BY).

http://creativecommons.org/licenses/by/4.0/

(c) (i) Open Access

\begin{abstract}
Mucor pepsin, a protease used in milk coagulation, is purified by ion-exchange and by molecular exclusion on Sephadex G100. The molecular weight (MW) is determined by polyacrylamide gel electrophoresis under denaturing conditions in presence of sodium dodecyl sulfate (SDS) and by molecular exclusion chromatography. Approximate evaluation of molecular mass was conducted by elution of known MW proteins (BSA: $67 \mathrm{kDa}$, pepsin: $35 \mathrm{kDa}$ and trypsin: $23.8 \mathrm{kDa}$ ) on Sephadex G-100 under the same conditions as the experimental sample. The electrophoretic profile shows that the active fraction studied appears as a single homogeneous band (monomeric form). According to the curve calibration, the molecular mass of the coagulant fraction is about $48 \mathrm{kDa}$. For Mucor, the observed MW value seems to be enigmatic. However, this result is confirmed by a proteomic analysis with close MW values obtained using conventional techniques. The protease studied by the Scafold ver. Software 2.0 and the analysis of the protein similarities indicate a MW of $46 \mathrm{kDa}$ and the protease sequence of 427 amino acids.
\end{abstract}

\section{Keywords}

Protease, Molecular Weight, Molecular Exclusion, Electrophoresis, Proteomics

\footnotetext{
${ }^{*}$ Corresponding author.
} 


\section{Introduction}

Milk-clotting enzymes have an important role in the process of cheese maturation [1]. Microbial rennet appears to be more promising because its production is cheaper, biochemical diversity is greater, and genetic modification is easier [2]. Consequently, researchers focus on microbial MCEs (milk-clotting enzymes). The enzymes from some fungi such as Rhizomucor, Mucor pusillus, Endothiaparasitica and others microbial sources, have been reported [3] and some biochemical properties have been studied. Indeed, in the field of the analysis and characterization of bioactive molecules, molecular mass determination is essential in the identification of the molecule. In macromolecular organic chemistry (organic polymers: proteins, nucleic acids, viruses, etc.), the problem of the determination of the molecular mass is more complex. Indeed, these macromolecular substances have, in most cases, the size and relatively high molecular masses. In addition, with rare exceptions, macromolecular compounds exhibit a significant heterogeneity of mass defined by the role of the substance. For example, most $\mathrm{Ba}$ cillus milk-clotting enzyme described in the literature give molecular size of $34 \mathrm{kDa}$ [1] or $65 \mathrm{kDa}$ [4].

The purpose of this article is to describe an approach to a fairly accurate assessment of the molecular mass of a protease from a culture of a strain of Mucor pusillus through the employment and subsequent three techniques.

\section{Materials and Methods}

\subsection{Protocol for the Production of Protease}

Protease that was to be the subject of the study of molecular mass was extracted from a fungal strain of Mucor pusillus referenced 953771, from in lyophilized form from the laboratory of Cryptogamy, the National Museum of Natural History in Paris. The transplanting of the strain was undertaken at the Laboratory of Food Technology of the National Institute of Agronomy (Algeria). The culture medium used was solid (surface fermentation), as advocated by Levadoux et al. [5]. It is composed of $60 \mathrm{~g}$ of wheat and $10 \mathrm{~mL}$ of $0.01 \%$ ammonium sulphate solution. After seeding, the boxes of Petri dishes containing malt agar medium, and their incubation at $37^{\circ} \mathrm{C}$ for 5 days, the spores were released using a $0.1 \%$ tween 80 solution. The spore suspension was filtered on the sterile glass wool. The cellular exoenzyme was extracted with phosphate $(0.02 \mathrm{M}, \mathrm{pH} 6)$ buffer.

\subsection{Purification Technics}

A double purification of the crude protease was made. This was achieved using an ion (anion exchanger) exchange chromatography followed by molecular exclusion on a Sephadex gel column. This was necessary for the study of protein homogeneity of protease and amino acids (proteomic analysis) sequence.

\subsection{Comparative Methods of Assessment of the Molecular Weight of the Purified Protease}

\subsubsection{Molecular Exclusion Chromatography}

Separation was achieved in decreasing order of molecular weight on the gel Sephadex G-100 with the help of a column $(1 \times 60 \mathrm{~cm})$ Pharmacia calibrated by a phosphate buffer solution $(0.02 \mathrm{M}$; pH 6). Aliquot $1.5 \mathrm{~mL}$ sample was eluted with the same buffer at a flow rate of $2 \mathrm{~mL} / \mathrm{h}$. Optical density reading was carried out at $280 \mathrm{~nm}$. Fractions with a coagulant activity were collected, concentrated, and then kept. Approximate evaluation of molecular mass was conducted by elution of known molecular weight proteins (BSA: $67 \mathrm{kDa}$, pepsin: $35 \mathrm{kDa}$ and trypsin: $23.8 \mathrm{kDa}$ ) on Sephadex G-100 column under the same conditions as our purified coagulase.

\subsubsection{PAGE-SDS Electrophoresis}

At each stage of purification, a sample was kept frozen or freeze-dried for electrophoresis according to Laemmli [6] in order to check homogeneity and the purity of the enzyme. The different samples and markers, volume to volume in the sample buffer, separated on a polyacrylamide gel which then formed a gel separation at $12 \%$ and a $5 \%$ concentration gel. The electrophoretic migration was achieved through a "Max Fill Bioblock Scientific" electrophoresis system under the following conditions: voltage: $250 \mathrm{~V}, 12 \%$ and an amperage gel separation: 74 $\mathrm{mA}$, time: $1 \mathrm{~h}$ at $20^{\circ} \mathrm{C}$. Coagulase electrophoretic migration was performed parallel to that of known molecular weight markers (Phosphorylase: $94 \mathrm{kDa}$, bovine serum albumin: $67 \mathrm{kDa}$, ovalbumin: $43 \mathrm{kDa}$, carbonic anhydrase: $30 \mathrm{kDa}$, trypsin inhibitor: $20 \mathrm{kDa}$ and lactalbumin: $14 \mathrm{kDa}$ ). 


\subsection{Proteomic Analysis}

Sequencing of anticoagulant protease isolated from the Mucor pusillus strain study conducted at the centre of the CHU Laval Quebec Proteomics platform in Canada.

Digestion in gel proteins

The bands of interest extracted from gels were placed in 96-well plates then washed with distilled water. Enzymatic digestion with trypsin was performed using a Mass Prep liquid-handling robot (Waters, Milford, USA) according to the protocol described by Shevchenko et al. [7], with modifications suggested by Havlis et al. [8]. Proteins were reduced with $10 \mathrm{mM}$ DTT and alkyl with $55 \mathrm{mM}$ iodoacetamide. Trypsin digestion was performed using $105 \mathrm{mM}$ modified porcine trypsin (Sequencing grade, Promega, Madison, WI) at $58^{\circ} \mathrm{C}$ for $1 \mathrm{~h}$. The products of digestion were extracted using a solution containing $1 \%$ formic acid and $2 \%$ acetonitrile followed by a $1 \%$ formic acid solution and 50\% acetonitrile. The extracts were concentrated under vacuum and re-suspended in 8 $\mu \mathrm{l}$ of a solution containing $0.1 \%$ formic acid; $4 \mu \mathrm{l}$ of extract are analysed by mass spectrometry.

\subsubsection{Mass Spectrometry}

Samples of peptides were separated by chromatography online liquid capillary nano scale phase reverse (RPnanoLC) and analysed by electrospray mass spectrometry (ES-MS/MS). Peptides are separated through a Pico Frit column Bio Basic C18 column, $10 \mathrm{~cm} \times 0.075 \mathrm{~mm}$ internal diameter (New Objective, Woburn, MA) with a linear gradient composed of $2 \%-50 \%$ solvent B (acetonitrile $0.1 \%$ formic acid) in $30 \mathrm{~min}, 200 \mu \mathrm{l} / \mathrm{min}$ flow (obtained by splitting flow). The acquisition of mass spectra was carried out using the software Xcalibur (software version 2.0, on a scale of the spectrum between 400 and $2000 \mathrm{~m} / \mathrm{z}$ ) and analysed using the software Mascot (Matrix Science, London, UK; version 2.2.0).

\subsubsection{Protein Identification}

Protein identification was conducted in the Uniref 14.0 fungi (platform Proteomics CHU Laval) Bank Software Scaffold (version Scaffold 2-01, Proteome Software Inc., Portland, OR) which was used to validate the MS/MS spectra based on the identification of peptides and proteins. The identification of a single peptide protein should not be taken for granted. In general, it is necessary to identify at least two different peptides (with $95 \%$ probability and for each of the peptide scores) of the same protein to consider this protein as being present in the sample. The identified proteins by a single peptide or more than two peptides but with scores lower than $95 \%$ are present in the list for identification purposes only.

\section{Results}

The results obtained using the different techniques for evaluating the molecular weight of the studied protease confirm the use of chromatographic methods. The determination of the molecular weight by polyacrylamide gel electrophoresis in denaturing conditions, in the presence of SDS (Figure 1) and the approximate evaluation of

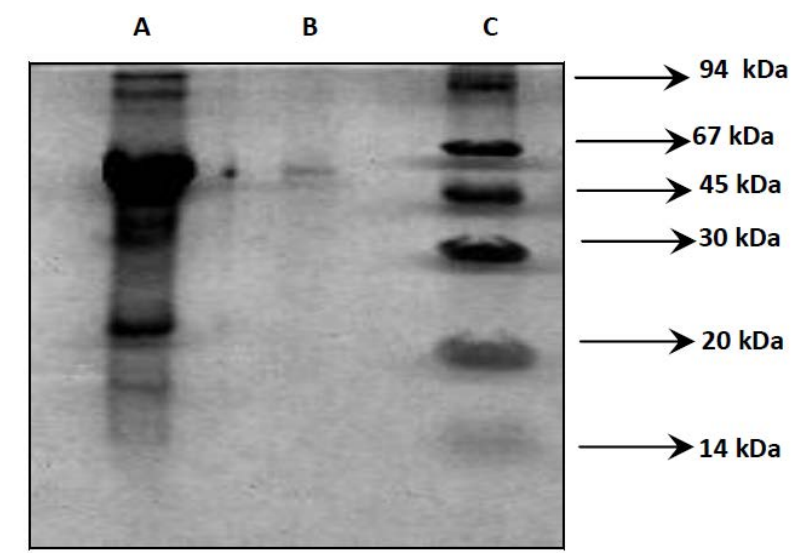

Figure 1. SDS-PAGE electro phoreotogram of Mucor pusillus extract. A: lyophilised crudeextract; B: purified extract on Sephadex G-100 filtration; C: standard molecular markers. 
mass performed by the elution of known molecular weight proteins (BSA: $67 \mathrm{kDa}$, pepsin: $35 \mathrm{kDa}$ and trypsin: $23.8 \mathrm{kDa}$ ) in Sephadex G-100 column (Figure 2) under the same conditions as the experimental sample (Figure 3) confirms our results. Molecular exclusion on Sephadex chromatography G-100 appears to be similar in the two methods.

The electrophoretic profile shows that the active fraction appears as one homogeneous band. Elution of purified protease produced a single peak of proteolytic activity. The value of PM obtained from the curve calibration markers to known weight and separated in the same conditions were in the order of $49 \mathrm{kDa}$. Although, the value of the obtained mass remains very high for a strain of the genus Mucor protease, it is clear that both techniques have analytical similarities by analysing proteomics with a PM.

In another component of the study, the protease sequencing (Figure 4) was conducted by a proteomic analysis in order to also determine the molecular mass of the protein. The study of protease using the Scaffold software and analysis of the similarities of proteins with a $95 \%$ probability of superior identifying did show a molecular weight of $46 \mathrm{kDa}$ for a sequence of protease of 427 amino acids (Figure 5 and Table 1).

\section{Discussion}

Proteomics, considered to be a very accurate technique in the analysis of proteins, confirms the results obtained

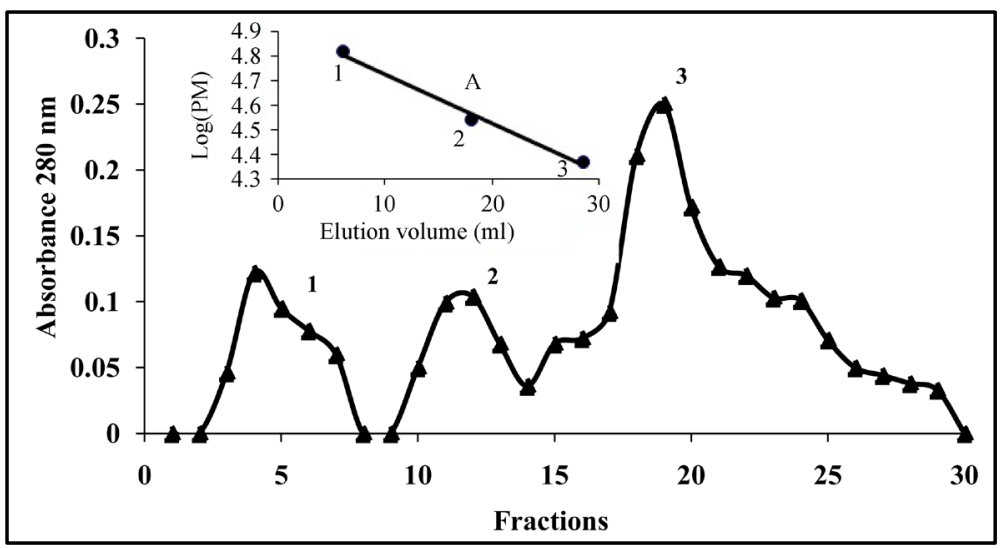

Figure 2. Gel filtration through Sephadex G-100 of standadr molecular markers (1) B.S.A.: $67 \mathrm{kDa}$; (2) pepsin: $35 \mathrm{kDa}$; (3) trypsin: $23.8 \mathrm{kDa}$. Pharmacia column $(1 \times 60 \mathrm{~cm})$, elution bufer phosphate: $(0.02 \mathrm{M}$; $\mathrm{pH}$ 6), flow rate: 2 $\mathrm{mL} / \mathrm{h}$, fraction: $1.5 \mathrm{~mL}$. A: etalon curve of standard protein $\operatorname{LogPM}=\mathrm{f}(\mathrm{Ve})$.

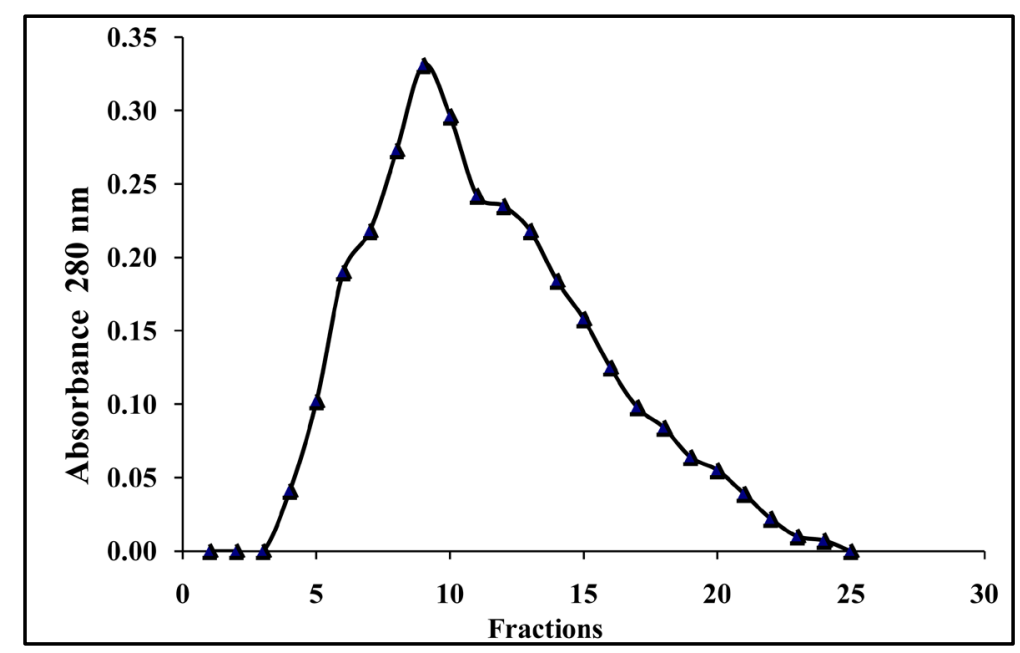

Figure 3. Gel filtration through Sephadex G-100 of Mucor pusillus (Pharmacia column $1 \times 60 \mathrm{~cm}$, elution buffer phosphate: $0.02 \mathrm{M}$; pH 6, flow rate: $2 \mathrm{~mL} / \mathrm{h}$, fraction: $1.5 \mathrm{~mL})$. 


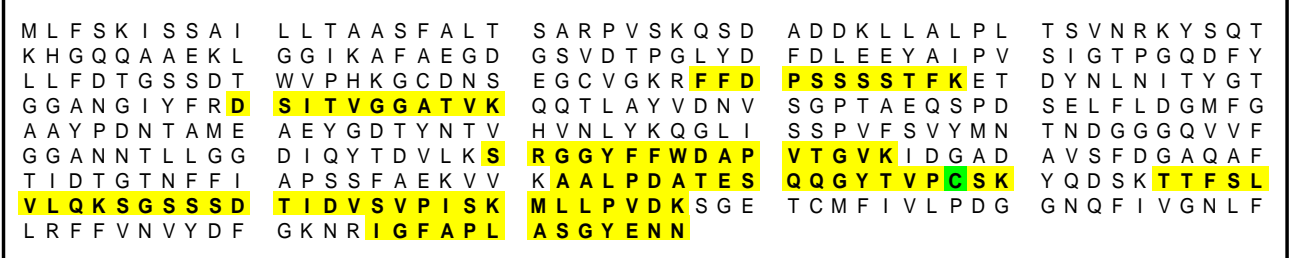

Figure 4. Amino acid sequence of the purified protease from Mucor pusillus (identification processing of proteins by Scafold Software 2.0).

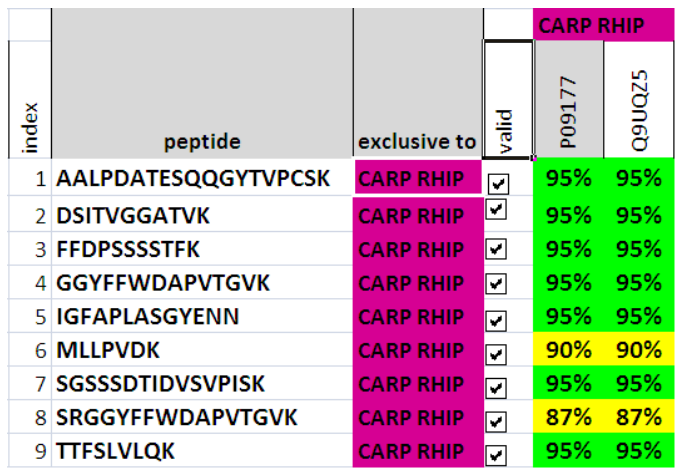

Figure 5. Identification of similar peptides (7 peptides) with probability at least $95 \%$ (yellow, disimilar peptides, for information only).

Table 1. Aminoacid sequence of the purified milk-clotting enzyme from Mucor pusillus and percentage of amino acids residue (\%).

\begin{tabular}{ccccccc}
\hline \multirow{2}{*}{ Aminoacids } & \multicolumn{2}{c}{ Results } & Amino acids & \multicolumn{2}{c}{ Results } \\
\cline { 2 - 3 } \cline { 5 - 6 } & Number of residue & Aminoacid residue (\%) & & Number of residue & Amino acid residue (\%) \\
\hline Alanine & 33 & 7.72 & Threonine & 32 & 7.49 \\
Valine & 31 & 7.25 & Cysteine & 4 & 0.93 \\
Leucine & 31 & 7.25 & Tyrosine & 19 & 4.44 \\
Isoleucine & 18 & 4.21 & Asparagine & 20 & 4.68 \\
Proline & 19 & 4.44 & Glutamine & 17 & 3.98 \\
Methionine & 6 & 1.40 & Aspartic acid & 34 & 7.96 \\
Phenylalanine & 29 & 6.79 & Glutamic acid & 14 & 3.27 \\
Tryptophan & 2 & 0.46 & Lysine & 22 & 5.15 \\
Glycine & 45 & 10.53 & Arginine & 7 & 1.63 \\
Serine & 41 & 9.60 & Histidine & 3 & 0.70 \\
Total & & & & $\mathbf{4 2 7}$ & $\mathbf{1 0 0}$ \\
\hline
\end{tabular}

by conventional methods. With a difference in the order of $3 \mathrm{kDa}$ or about 6 percent of the mass obtained with the SDS-Page and molecular exclusion, these results seem very close to that obtained with the other methods. Nevertheless, in commenting on these results, they do not coincide with those reported in the literature. According to Areces et al. [9] cited by Fernandez-Lahore et al. [10], fungal proteases are characterized usually by a molecular weight ranging from 32 to $34 \mathrm{kDa}$. This result is confirmed by some authors [1] [10]-[12], by studying the purified coagulases from Mucor renninus, Penicilliumcaseicolum, Mucor sp., and Rhizopusoryzae, respectively. Xiaoling et al. [3] reported that the purified enzyme from Bacillus amyloliquefaciens has a molecular mass of $58.2 \mathrm{kDa}$ determined by SDS-Page, which is higher than those in the literature (34 - $49 \mathrm{kDa}$ ) for other microbial milk-clotting enzymes measured by gel filtration. 
The molecular weight difference indicates that this feature depends on the origin of the coagulase, so further work on animal coagulases with reported molecular weight between 31 and $37 \mathrm{kDa}$ [13] need to be performed. According to Garnot \& Martin [14], chymosin and pepsin are characterized by a mass of $30 \mathrm{kDa}$ and $35 \mathrm{kDa}$, respectively. Furthermore, the molecular weight in the order of 67 and $62 \mathrm{kDa}$ has been reported for the coagulase of vegetable origin [15] [16].

\section{Conclusions}

The results obtained with the different techniques for evaluating the molecular weight of the protease confirm the use of chromatographic methods. The electrophoretic profile shows that the active fraction appears one homogeneous band and elution of purified protease gave a single peak of proteolytic activity. The value of PM obtained by the methods listed is in the order of $49 \mathrm{kDa}$. Although the value of the obtained mass remains very high for a strain of the genus Mucor protease, it is clear that both techniques have analytical similarities confirmed by a proteomic analysis with a molecular mass in the order of $46 \mathrm{kDa}$.

Proteomics, considered to be a very accurate technique in the analysis of proteins, confirms the results obtained by classical methods with the order of $3 \mathrm{kDa}$ difference observed between the values of PM observed. Furthermore, this trial result could well be explained by a mutation of the strain in different experiments conducted on Mucor pusillus.

\section{References}

[1] Kumar, S., Sharma, N.S., Saharan, N.R. and Singh, R. (2005) Extracellular Acid Protease from Rhizopusoryzae Purification and Characterization. Process Biochemisty, 40, 1701-1705. http://dx.doi.org/10.1016/j.procbio.2004.06.047

[2] Zhang, Z.G., Wang, C.Z., Yao, Z.Y., Zhao, J.F., Lu, F.X., Yu, G.M., Lan, W.J. and Lu, Z.X. (2011) Isolation and Identification of a Fungal Strain QY229 Producing Milk-Clotting Enzyme. European Food Research and Technology, 232, 861-866. http://dx.doi.org/10.1007/s00217-011-1454-4

[3] He, X.L., Ren, F.Z., Guo, H.Y., Zhang, W.B., Song, X. and Gan, B.Z. (2011) Purification and Properties of a Milk-Clotting Enzyme Produced by Bacillus amyloliquefaciens D4. Korean Journal of Chemical Engineering, 28, 203-208. http://dx.doi.org/10.1007/s11814-010-0347-8

[4] Ageitos, J.M., Vallejo, J.A., Sestelo, A.B., Poza, M. and Villa, T.G. (2007) Purification and Characterization of a MilkClotting Protease from Bacillus licheniformis Strain USC13. Journal of Applied Microbiology, 103, 2205-2213. http://dx.doi.org/10.1111/j.1365-2672.2007.03460.x

[5] Levadoux, W., Johnson, M. and Ander, G. (1989) Monitoring the Degradation of Commercial Microbial Rennet Preparations. Journal of Dairy Science, 72, 627-634. http://dx.doi.org/10.3168/jds.S0022-0302(89)79153-0

[6] Laemmli, U.K. (1970) Cleavage of Structural Proteins during the Assembly of the Head of Bacteriophage T4. Nature, 227, 680-685. http://dx.doi.org/10.1038/227680a0

[7] Shevchenko, A., Wilm, M., Vorm, O. and Mann, M. (1996) Mass Spectrometric Sequencing of Proteins from SilverStained Polyacrylamide Gels. Analytical Chemistry, 68, 850-858. http://dx.doi.org/10.1021/ac950914h

[8] Havlis, J., Thomas, H., Sebela, M. and Shevchenko, A. (2003) Fast-Response Proteomics by Accelerated In-Gel Digestion of Proteins. Analytical Chemistry, 75, 1300-1306. http://dx.doi.org/10.1021/ac026136s

[9] Areces, L.B., Bonino, M.B.I., Parry, M.A.A., Fraile, E.R., Fernandez, H.M. and Cascone, O. (1992) Purification and Characterization of a Milk Clotting Protease from Mucor bacilliformis. Applied Biochemistry and Biotechnology, 37, 283-294. http://dx.doi.org/10.1007/BF02788880

[10] Fernandez-Lahore, H.M., Fraile, E.R. and Cascone, O. (1998) Acid Protease Recovery from a Solid-State Fermentation System. Journal of Biotechnology, 62, 83-93. http://dx.doi.org/10.1016/S0168-1656(98)00048-0

[11] Belyauskaite, I.P., Palubinskas, V.J., Ancheuko, O.E., Vesa, V.S. and Glemzha, A.A. (1980) Purification and Some Properties of the Extracellular Acid Proteases from Mucor renninus. Enzyme and Microbial Technology, 2, 37-44. http://dx.doi.org/10.1016/0141-0229(80)90006-X

[12] Lenoir, J., Auberger, B. and Grippon, J.C. (1979) Les caractères du système protéolytique de Penicillium caseicolum. III. Caractérisation d'une protéase acide. Le Lait, 585-586, 244-268. http://dx.doi.org/10.1051/lait:1979585-58613

[13] Fox, P.F. and Whitaker, J.R. (1977) Isolation and Charaterization of Sheep Pepsin. Biochemical Journal, 161, $389-398$.

[14] Garnot, P. and Martin, P. (1980) Présure, composition, activité, son rôle en fromagerie. Technique Laitière, 930, 27-30.

[15] Lorente, B.E., Brutti, C.B. and Caffini, N.O. (2004) Purification and Characterization of a Milk-Clotting Aspartic Proteinase from Globe Artichoke (Cynarascolymus L.). Journal of Agriculture and Food Chemistry, 52, 8182-8189. 
N. Abdelouahab et al.

http://dx.doi.org/10.1021/jf0490060

[16] Sidrach, L., Garcia-Canovas, F., Tudela, J. and Neptuno Rodriguez-Lopez, J. (2005) Purification of Cynarases from Artichoke (Cynarascolymus): Enzymatic Properties of Cynarase A. Phytochemistry, 66, 41-49. http://dx.doi.org/10.1016/j.phytochem.2004.10.005 